УДК 616.75-071:617.559:616.711-007.271-053

\title{
Педаченко Ю.С. ${ }^{1,2}$, Красиленко О.П., 3
}

${ }^{1}$ Відділення малоінвазивної та лазерної спінальної нейрохірургії, Інститут нейрохірургії ім. акад. А.П.Ромоданова НАМН України, м. Київ, Україна

${ }^{2}$ Кафедра нейрохірургії, Національна медична академія післядипломної освіти імені П.Л. Шупика МОЗ України, м. Київ, Україна

${ }^{3}$ Відділ загальної лікарняної практики, Інститут ядерної медицини та променевої діагностики НАМН України, м.Київ, Україна

\section{Клінічні прояви лігаментозу при стенозі поперекового відділу хребтового каналу у хворих різного віку}

Вступ. Лігаментоз поперекового відділу хребтового каналу - досить рідкісна й недостатньо вивчена патологія.

Матеріали і методи. 3 загальної кількості хворих, оперованих з приводу стенозу хребтового каналу, виділені хворі з ознаками лігаментозу зв'язкового апарату.

Результати. Вивчене поширення інтраканального лігаментозу та зумовлені ним особливості клінічного перебігу стенозу поперекового відділу хребтового каналу у 45 оперованих хворих різного віку.

Висновки. При патології зв'язок хребтового каналу виникає порушення біомеханіки хребта, що спричиняє більш виражене звуження просвіту хребтового каналу і впливає на тяжкість клінічного перебігу стенозу хребтового каналу в поперековому відділі. Частіше виявляють у хворих старшого віку.

Ключові слова: стеноз поперекового відділу хребтового каналу, лігаментоз, нейрогенна переміжна кульгавість, задня поздовжня зв'язка, жовта зв'язка.

Вступ. Проблемі інтраканального лігаментозу як чинника нейрокомпресійних синдромів хребта останнім часом приділяють все більше уваги. Більшість досліджень присвячені дегенеративним змінам зв'язок у шийному відділі хребта [1-3], повідомлення про ці зміни у поперековому відділі поодинокі.

Сьогодні як окрему нозологічну фрорму вертеброгенної шийної патології виділяють осифікацію задньої поздовжньої зв'язки (ЗПЗ). Ї̈̈ ізольоване ураження спричиняє мієло- та/або радикулопатію без додаткових фракторів компресії [4-6]. Зміни зв'язкового апарату більшого чи меншого ступеня супроводжують дегенеративні зміни хребта з формуванням неврологічних симптомів майже у $33 \%$ спостережень [7], є додатковою причиною компресії, погіршують результати хірургічного лікування хворих $[8,9]$.

Патології жовтих зв'язок (Ж3), а також змінам зв'язкового апарату на поперековому та грудному рівнях приділяють значно менше уваги $[10,11]$.

В той же час, не з'ясоване клінічне значення і особливості перебігу стенозуючого лігаментозу у поперековому відділі хребта. Потребує оптимізації хірургічна тактика при цій патології.

Мета роботи - вивчення поширення, клінічних ознак та особливостей хірургічного лікування ліга- ментозу поперекового відділу, що зумовлює стеноз хребтового каналу у хворих різного віку.

Матеріали і методи дослідження. 3 загальної кількості хворих (570), оперованих з приводу стенозу поперекового відділу хребтового каналу, у клініці ендоскопічної та лазерної нейрохірургії в період 3 2002 по 2010 р. виділено групу з 45 пацієнтів, у яких діагностований супутній стенозуючий інтраканальний лігаментоз.

Ми не можемо говорити про ізольований лігаментоз, оскільки ця патологія була одним з чинників стенозування хребтового каналу, що супроводжувала кістково-суглобові зміни та супутній рубцево-спайковий епідуріт.

За класифікацією ВООЗ (1983), хворі розподілені на групи відповідного віку:

- молодий - від 15 до 29 років

- зрілий - від 30 до 44 років

- середній — від 45 до 59 років

- похилий - від 60 до 74 років

- старечий - 75 років і старше.

Вік оперованих загальної групи від 16 до 80 років, у середньому (48 \pm 12$)$ років; хворих з лігаментозом - $(52 \pm 12)$ років $(\mathrm{P}<0,05)$.

Результати розподілу оперованих в загальній групі та в групі з інтраканальним лігаментозом за віком представлені у табл. 1 .

Таблиия 1. Залежність частоти виявлення інтраканального лігаментозу у хворих при стенозі поперекового відділу хребтового каналу від віку

\begin{tabular}{|c|c|c|c|c|c|c|c|c|c|c|}
\hline \multirow{4}{*}{ Вік, років } & \multicolumn{8}{|c|}{ Лігаментоз } & \multicolumn{2}{|c|}{ Загалом } \\
\hline & \multicolumn{6}{|c|}{$\mathbf{E}$} & \multicolumn{2}{|c|}{ нема } & \multirow{3}{*}{ абс. } & \multirow{3}{*}{$\%$} \\
\hline & \multicolumn{2}{|c|}{$3 \Pi 3$} & \multicolumn{2}{|c|}{ ЖКЗ } & \multicolumn{2}{|c|}{ pasom } & \multirow[b]{2}{*}{ абс. } & \multirow{2}{*}{$\%$} & & \\
\hline & абс. & $\%$ & абс. & $\%$ & абс. & $\%$ & & & & \\
\hline $15-29$ & 0 & 0 & 3 & 10,4 & 3 & 10,4 & 26 & 89,7 & 29 & 100 \\
\hline $30-44$ & 2 & 1,0 & 5 & 2,5 & 7 & 3,6 & 190 & 96,5 & 197 & 100 \\
\hline $45-59$ & 6 & 2,4 & 18 & 7,2 & 24 & 9,6 & 226 & 90,4 & 250 & 100 \\
\hline $60-74$ & 1 & 1,1 & 9 & 9,9 & 10 & 11,2 & 79 & 88,8 & 89 & 100 \\
\hline 75 і старше & 0 & 0 & 1 & 20,0 & 1 & 20,0 & 4 & 80,0 & 5 & 100 \\
\hline Загалом & 9 & 1,6 & 36 & 6,3 & 45 & 7,9 & 525 & 92,1 & 570 & 100 \\
\hline
\end{tabular}


Під час аналізу брали до уваги поширення лігаментозу ЗПЗ та ЖЗ при стенозі хребтового каналу у поперековому відділі (моносегментарний або полісегментарний тип).

Виявляли нейрокомпресійні синдроми стенозу поперекового відділу хребтового каналу: радикулопатію (включаючи перманентну та транзиторну, моно- чи полісегментарний тип), синдром переміжної кульгавості.

Результати та їх обговорення. Дегенеративні зміни ЗПЗ у шийному відділі, за даними літератури, в європейській популяції виявляють з частотою $0,16 \%$ [12]. У літературі ми не знайшли відомостей про частоту лігаментозу у поперековому відділі хребта. В оперованих нами хворих з приводу стенозу хребтового каналу в поперековому відділі осифікації зв'язок не було, проте, гіпертрофію зв'язок спостерігали у $7,9 \%$ хворих.

Дегенеративні зміни зв“язкового апарату починають формуватись вже у молодому віці [13]. Зміни зв'язкового апарату стрімко формуються на 4-му десятиріччі життя [3]. Отримані нами результати співпадають 3 даними літератури.

Стенозуючу патологію жЗ діагностують у хворих всіх вікових груп. В молодому віці ї̈ частота навіть більша, ніж у зрілому. Крім дегенеративнодистрофічних змін, характерних для остеохондрозу, виникненню лігаментозу сприяє травматичне ураження. Травма як провокуючий чинник формування неврологічних симптомів, за даними анамнезу встановлена у 4 хворих молодого та зрілого віку 3 лігаментозом Ж3.

3 наведених даних можна зробити висновок, що зміни у ЖЗЗ на поперековому рівні виникають частіше, ніж у ЗПЗ.

Ж3 належать до коротких парних інтраканальних зв'язок. Вони заповнюють проміжки між дугами хребців від $\mathrm{C}_{\text {II }}$ до крижової кістки. Прямують від внутрішньої поверхні і нижнього краю дуги хребця, розташованого вище, до зовнішньої поверхні та верхнього краю нижче розташованого хребця. Передніми краями вони ззаду відмежовують міжхребцевий отвір. Через високу пружність та еластичність ЖЗ здатні до скорочення під час розгинання хребта і діють подібно м'язам. Так само вони діють при розгинанні.

ЗПЗ належить до довгих зв'язок хребта. Функціонально є антагоністом передньої поздовжньої зв'язки і обмежує надмірне згинання хребта. ЗПЗ розташована на задній поверхні тіл хребців безпосередньо у хребтовому каналі. Починається на задній поверхні $\mathrm{C}_{\mathrm{II}}$ хребця, закінчується у крижовому каналі. Вона нещільно зв'язана з тілами хребців, проте, міцно - 3 міжхребцевими дисками. Найбільше розвинена у шийному відділі. Саме цим можна пояснити переважну частоту її осифікації у верхніх відділах хребта. У поперековому відділі дегенерація ЗПЗ частіше виникає на рівні верхніх хребців [14].

Залежно від поширення вздовж хребта виділяють декілька типів осифікації ЗПЗ.

- фрокальна осифікація задньої поверхні тіла хребця

- сегментарна в межах одного хребтово-рухового сегмента

- безперервна на кількох рівнях

- змішаний тип.
За фрормою поверхні розрізняють рівну, дзьобоподібну (зі значним вистоянням у бік хребтового каналу на рівні міжхребцевих дисків), безперервно хвилеподібну, змішану форми.

Осифікація інтраканальних зв'язок візуалізується за даними рентгенологічного дослідження та КТ, на якій у ділянці зв'язки спостерігають гіперінтенсивний сигнал. У оперованих хворих з гіпертрофічним лігаментозом на МРТ спостерігали потовщення Ж3 (більше 5 мм), гіперінтенсивний сигнал від неї [15]. Встановлено пряму кореляцію між інтенсивністю сигналу та ступенем інтраопераційно візуалізованої гіпертрофії зв'язок.

Наведені у табл. 2 дані дозволяють співставити частоту виявлення окремих нейрокомпресійних синдромів з рівнем змін зв'язок хребтового каналу.

У 9 хворих спостерігали зміни зв'язок на кількох рівнях

Таким чином, у 45 хворих діагностовані 55 неврологічних синдромів, значною мірою зумовлених патологією зв'язкового апарату. У 2 хворих спостерігали поєднання гіпертрофічних змін ЖЖЗ та ЗПЗ на кількох рівнях.

У групах з найбільшою кількістю спостережень (хворі віком від 45 до 59 років та у загальній) встановлено залежність характеру нейрокомпресійних симптомів від типу лігаментозу. Так, за наявності дегенеративних змін у ЗПЗ частіше спостерігали каудоішемічний синдром, зміни Ж3 частіше асоціюються з радикулоішемічним синдромом.

Дегенеративним змінам зв“язок хребта поза хребтовим каналом (передньої поздовжньої, міжпоперечної, міжостистих, надостистої) клініцисти не приділяють належної клінічної уваги.

Міжостисті зв'язки заповнюють проміжок між остистими відростками двох суміжних хребців. Мінімально виражені у шийному відділі, вони найбільш розвинені у поперековому відділі. Спереду вони сполучаються з Ж3. При зменшенні еластичності та довжини цих утворень обмежується вертикальний розмір міжхребцевого отвору, поглиблюється його стеноз.

3570 хворих, оперованих з приводу стенозу поперекового відділу хребта, гіпертрофічні зміни міжостистих зв'язок спостерігали у 44.

Висновки. 1. Патологія зв'язок хребтового каналу спричиняє порушення біомеханіки хребта, більш виражене звуження просвіту хребтового каналу,

Таблиця 2. Розподіл хворих за рівнем ураження хребта, видом лігаментозу та нейрокомпресійним синдромом, що його супроводжує

\begin{tabular}{|c|c|c|c|c|}
\hline \multirow[b]{2}{*}{$\begin{array}{c}\text { Уражений } \\
\text { сегмент }\end{array}$} & \multirow[b]{2}{*}{$\begin{array}{c}\text { Вид лі- } \\
\text { гамен- } \\
\text { тозу }\end{array}$} & \multicolumn{2}{|c|}{$\begin{array}{c}\text { Нейрокомпресійний } \\
\text { синдром }\end{array}$} & \multirow[b]{2}{*}{ Разом } \\
\hline & & $\begin{array}{c}\text { радикуло- } \\
\text { патія }\end{array}$ & $\begin{array}{c}\text { переміж- } \\
\text { на ней- } \\
\text { рогенна } \\
\text { куль- } \\
\text { гавість }\end{array}$ & \\
\hline \multirow{2}{*}{$\mathrm{L}_{\mathrm{II}}-\mathrm{L}_{\mathrm{III}}$} & $3 \Pi 3$ & - & - & - \\
\hline & ※3 & 1 & - & - \\
\hline \multirow{2}{*}{$\mathrm{L}_{\mathrm{III}}-\mathrm{L}_{\mathrm{IV}}$} & $3 \Pi 3$ & 1 & 2 & 3 \\
\hline & Ж⿱一𫝀З & 1 & 3 & 4 \\
\hline \multirow{2}{*}{$\mathrm{L}_{\mathrm{IV}}-\mathrm{L}_{\mathrm{V}}$} & $3 \Pi 3$ & 3 & 4 & 7 \\
\hline & 胥3 & 22 & 8 & 30 \\
\hline \multirow{2}{*}{$\mathrm{L}_{\mathrm{V}}-\mathrm{S}_{\mathrm{I}}$} & $3 \Pi 3$ & - & 2 & - \\
\hline & Жૉ3 & 7 & 1 & 8 \\
\hline \multirow{2}{*}{ Загалом } & ЗПЗ & 4 & 8 & 12 \\
\hline & 䄳 & 31 & 12 & 43 \\
\hline
\end{tabular}


що впливає на тяжкість клінічних проявів стенозу хребтового каналу в поперековому відділі.

2. Найбільш клінічно значущими є гіпертрофрія ЗПЗ та ЖЗ. Дистрофічні зміни у ЗПЗ частіше супроводжуються синдромом нейрогенної переміжної кульгавості, ЖЗ - радикулопатією.

3. Патологія зв'язкового апарату здебільшого притаманна хворим старшого віку, хоча може виникати і в молодому віці.

\section{Список літератури}

1. Ossification of the posterior longitudinal ligament: a review / K. Saetia, D. Cho, S. Lee [et al.] // Neurosurg. Focus. -2011 . - V.30, N3. - E1.

2. Inter- and intraobserver variability of a cervical OPLL classification using reconstructed CT images / H. Chang, C.G. Kong, H.Y. Won [et al.] // Clin. Orthop. Surg. - 2010. - V.2. - P.8-12.

3. Computer-assisted measurement of the size of ossification in patients with ossification of the posterior longitudinal ligament in the cervical spine / K. Chiba, Y. Kato, N. Tsuzuki [et al.] // J. Orthop. Sci. — 2005. — V.10. — P.451456.

4. Griffiths I.D. Cervical myelopathy, ossification of the posterior longitudinal ligament, and diffuse idiopathic skeletal hyperostosis: problems in investigation / I.D. Griffiths, T.P. Fitzjohn // Ann. Rheum. Dis. - 1987. - V.46. - P.166-168.

5. Treatment of myelopathy due to cervicothoracic OPLL via open door laminoplasty / M. Komagata, Y. Inahata, M. Nishiyama [et al.] // J. Spin. Disord. Tech. — 2007. — V.20. - P.342-346.

6. Cervical myelopathy due to OPLL: clinical evaluation by MRI and intraoperative spinal sonography / Y. Matsuyama, N. Kawakami, M. Yanase [et al.] // J. Spin. Disord. Tech. - 2004. — V.17. - P.401-404.

7. Min J.H. Significance of the double- and single-layer signs in the ossification of the posterior longitudinal ligament of the cervical spine / J.H. Min, J.S. Jang, S.H. Lee // J. Neurosurg. Spine. - 2007. - V.6 - P.309-312.

8. Mizuno J. Outcome analysis of anterior decompressive

Педаченко Ю.Е.', ${ }^{1,}$ Красиленко Е.П. ${ }^{1,3}$

${ }^{1}$ Отделение малоинвазивной и лазерной спинальной нейрохирургии, Институт нейрохирургии им. акад. А. П. Ромоданова НАМН Украины, г. Киев, Украина

${ }^{2}$ Кафедра нейрохирургии, Национальная академия

последипломного образования имени П.Л. Шупика МЗ Украины, г. Киев, Украина

${ }^{3}$ Отделение общей лечебной практики, Институт ядерной медицины и лучевой диагностики НАМН Украины, г. Киев, Украина

Клинические проявления лигаментоза при стенозе поясничного отдела позвоночного канала у больных разного возраста

Вступление. Лигаментоз поясничного отдела позвоночного канала является относительно редкой и недостаточно изученной патологией.

Материалы и методы. Из общего числа больных, оперированных по поводу стеноза позвоночного канала, выделены больные с признаками лигаментоза связочного аппарата позвоночника.

Результаты. Изучена распространенность интраканального лигаментоза и обусловленные им особенности клинического течения стеноза поясничного отдела позвоночного канала у 45 оперированных больных разного возраста. surgery and fusion for cervical ossification of the posterior longitudinal ligament: report of 107 cases and review of literature / J. Mizuno, H. Nakagawa // Neurosurg. Focus. - 2001. - V.10, N4. - E6.

9. Choice of surgical approach for ossification of the posterior longitudinal ligament in combination with cervical disc hernia / H.S. Yang, D.Y. Chen, X.H. Lu [et al.] // Eur. Spine J. - 2010. - V.19. - P.494-501.

10. Thoracic myelopathy secondary to ossification of the spinal ligament / K. Yonenobu, S. Ebara, K. Fujiwara [et al.] // J. Neurosurg. - 1987. - V.66 - P.511-518.

11. Paravertebral ligamentous ossification: DISH, OPLL and OFL / S. Ehara, T. Shimamura, R. Nakamura [et al.] // Eur. J. Radiol. - 1998. - V.27. - P.198-205.

12. Tsuyama N. Ossification of the posterior longitudinal ligament of the spine / N. Tsuyama // Clin. Orthop. Relat. Res. - 1984. - V.184. - P.71-84.

13. Hori T. How does the ossification area of the posterior longitudinal ligament thicken following cervical laminoplasty? / T. Hori, Y. Kawaguchi, T. Kimura // Spine. - V.32. - E551-E556.

14. Синельников Р.Д. Атлас анатомии человека: учеб. пособие. - 2-е изд., стереотип.; в 4 т. / Р.Д. Синельников, Я.Р. Синельников. - М.: Медицина, 1996. - Т.1. - С.140-143

15. Дегенеративно-дистрофические поражения позвоночника (лучевая диагностика, осложнения после дискэктомии): руководство для врачей / Т.Е. Рамешвили, Г.Е. Труфанов, Б.В. Гайдар, В.Е. Парфенов. - СПб.: ЭЛБИ-СПб, 2011. — 218 с.

Надійшла до редакизї 24.03.12 Прийнята до публікаиії 28.05.12

Адреса для листування:

Педаченко Юрій Свгенійович 04050, Київ, вул. Платона Майбороди, 32 Інститут нейрохірургї ім. акад. А.П. Ромоданова НАМН України відділення малоінвазивної та лазерної спінальної нейрохірургї e-mail: pedachenko_yura@mail.ru

Выводы.При патологии связок позвоночного канала нарушается биомеханика позвоночника, что обусловливает более выраженное сужение позвоночного канала и влияет на тяжесть клинического течения стеноза позвоночного канала в поясничном отделе. Чаще выявляют у больных старшего возраста.

Ключевые слова: стеноз поясничного отдела позвоночного канала, лигаментоз, нейрогенная перемежающаяся хромота, задняя продольная свлзка, желтая связка.

Поступила в редакцию 24.03.12 Принята к публикащии 28.05.12

Адрес для переписки: Педаченко Юрий Евгенвевич 04050, Киев, ул. Платона Майбородъ, 32 Институт нейрохирурги

им. акад. А.П. Ромоданова НАМН Украинъ отделение малоинвазивной и лазерной спинальной нейрохирургии e-mail: pedachenko_yura@mail.ru 
Pedachenko Yu.E. 1,2, Krasilenko E.P. ${ }^{1,3}$

${ }^{1}$ Department of Miniinvasive and Laser Spinal Neurosurgery, Institute of Neurosurgery named after acad. A.P. Romodanov NAMS Ukraine, Kiev, Ukraine

${ }^{2}$ Department of Neurosurgery, National Medical Academy of Postgraduate Education named after P.L. Shupik of Ministry of Healthcare of Ukraine, Kiev, Ukraine

${ }^{3}$ Department of General Medical Practice, Institute of Nuclear Medicine and Radiology NAMS Ukraine, Kiev, Ukraine

Clinical features of ligamentosis in lumbar spinal stenosis in patients of different age

Introduction. Ligamentosis of lumbar spinal canal are rare and not well investigated pathology.

Materials and methods. From our patients with lumbar spinal stenosis we took that, which had changes in spinal ligaments

Results. We studied incidence of intracanal ligamentosis, caused by them features in clinic of lumbar spinal stenosis in 45 patients.

Conclusions. Pathology of ligaments leads to changes of spinal biomechanic, narrowing of spinal canal and has influence to clinical features of lumbar spinal stenosis. Pathology is more common for patients in senior age.

Key words: lumbar spinal stenosis, ligamentosis, neurogenic spinal claudication, yellow ligament, posterior longitudinal ligament.

Received March 24, 2012 Accepted May 28, 2012

Address for correspondence: Yuriy Pedachenko 04050, 32 Platon Maiboroda St., Kiev, Ukraine Institute of Neurosurgery named after acad. A.P. Romodanov NAMS Ukraine, Department of miniinvasive and laser spinal neurosurgery e-mail: pedachenko_yura@mail.ru

\section{Коментар до статті Педаченка Ю.Є., Красиленко О.П. «Клінічні прояви лігаментозу при стенозі поперекового відділу хребтового каналу у хворих різного віку»}

Робота присвячена важливій і доволі поширеній не тільки в Україні, а й у світі проблемі інтраканального лігаментозу як чиннику нейрокомпресійних синдромів хребта, якій останнім часом приділяють все більше уваги. Автори показали, що зміни зв'язкового апарату супроводжують дегенеративні зміни хребта з появою неврологічних симптомів, $\epsilon$ додатковою причиною компресії, погіршують результати хірургічного лікування. Стенозуюче ураження жовтих зв'язок, на жаль, діагностують у хворих усіх вікових груп, причому, її частота більша у молодому віці, ніж у зрілому. Автори виділяють, крім дегенеративно-дистрофічних змін при остеохондрозі, травматичне ураження як причину формування лігаментозу. Також важливим для планування оперативного втручання $\epsilon$ висновок, що зміни у жовтих зв'язках на поперековому рівні виникають частіше, ніж у задній поздовжній зв'язці (ЗПЗ). Автори виділяють декілька типів осифікації ЗПз залежно від поширення вздовж хребта (фокальна осифікація задньої поверхні тіла хребця, сегментарна в межах одного хребтово-рухового сегмента, безперервна на кількох рівнях, змішаний тип). Встановлено залежність вираженості нейрокомпресійних симптомів від типу лігаментозу. Так, за наявності дегенеративних змін у ЗПЗ частіше спостерігали каудоішемічний синдром, з змінами жовтих зв'язок частіше асоціюється радикулоішемічний синдром, що важливе для неврологів та нейрохірургів. Наголошено, що дегенеративним змінам зв'язок хребта поза хребто- вим каналом (передньої поздовжньої, міжпоперечної, міжостистих, надостистої) клініцисти не приділяють належної уваги.

Слід зазначити, що автори не висвітлили позицію деяких світових дослідників цієї проблеми про те, що лігаментоз $є$ вторинним механізмом захисту надмірної рухомості (нестабільності) ураженого остеохондрозом хребцево-рухового сегмента, що потребує деяко зміни методів дослідження та алгоритмів лікування хворих

Вражає загальна кількість матеріалу дослідження (570 хворих), оперованих з приводу стенозу поперекового відділу хребтового каналу за період 2002-2010 рр., з виділенням групи пацієнтів (45) з супутнім стенозуючим інтраканальним лігаментозом. Ретельно проаналізований матеріал поданий у вигляді сприйнятливих таблиць. На жаль, автори не навели катамнез оперованих хворих, типи і строки виконання оперативних втручань та їх результати, адже, це представляє найбільший інтерес для подальшого вивчення проблеми, неврологічної та нейрохірургічної оцінки якості життя пацієнтів. Проте, результати проведеного дослідження цікаві, на них варто зважати під час вибору методів лікування таких хворих.

Стаття Педаченка Ю.Є., Красиленка О.П. $€$ ще одним кроком до вирішення цієї проблеми. Стаття цікава та корисна для фахівців, які займаються проблемами лікування остеохондрозу хребта, як консервативного так і оперативного.

В.В. Вербов, кандидат мед. наук, нейрохірург відділення патології спинного мозку Інститут нейрохірургії ім. акад. А.П. Ромоданова НАМН України 